\section{Textual analysis of university mission statements in East Asian world-class universities}

\author{
Keenan Daniel Manning \\ University of Hong Kong, Hong Kong, China
}

University mission

statements

Received 3 September 2020 Revised 30 December 2020 Accepted 11 January 2021

\begin{abstract}
Purpose - The management of higher education institutions (HEIs) is undergoing a period of rapid development around the world and particularly in Asia. Competing forces of neoliberal decentralisation, increased government oversight, internationalisation and regionalism are creating difficulties for managers and stakeholders alike. This paper aims to look at the ways in which universities have institutionalised their strategies for coping with these forces, in the form of their mission statements (MSs), particularly within an East Asian context.

Design/methodology/approach - Several major international university ranking tables were used to compile a list of "world class" institutions in East Asia. Those with available MSs in English were examined for reference to factors existing within the literature, as well as those which were not previously identified.

Findings - East Asian universities placed a high degree of emphasis on aspects related to university management, as well as social, cultural and historical foci. Far less emphasis was placed on aspects such as engagement of stakeholders and inclusion.

Originality/value - The paper draws on previous research from other regions and attempts to provide some insights into the particularities of higher education in East Asia from a management perspective.
\end{abstract}

Keywords East Asia, Management, Mission statement, University

Paper type Research paper

\section{Introduction}

At the heart of the modern organisation are, or at least it is argued there should be, a set of core principles and a central "mission" (Pearce and David, 1987). Since the 1980s, there has been an assumption that all organisations with serious ambitions in their fields should have some codified record of this mission in the form of a "mission statement" (MS) (Kuenssberg, 2011) (also referred to as a "creed statement", a "statement of purpose" or a "statement of general principles" (David, 1989)). Despite the difficulty in doing so, pressure has forced many institutions of higher education to generate MSs of their own (Kuenssberg, 2011; Morphew and Hartley, 2006).

During these few decades, arguably the most significant forces shaping the development of higher education have been massification, accountability, governance, internationalisation, rankings and the emergence of world-class universities (Park, 2018; Shin and Hartman, 2009). These have created both opportunities and threats for developed and developing higher education systems alike, by exposing them to external pressure at the same time that markets are opened up to attract foreign talent and expertise to improve the quality of the education

(C) Keenan Daniel Manning. Published in Higher Education Evaluation and Development. Published by Emerald Publishing Limited. This article is published under the Creative Commons Attribution (CC BY 4.0) licence. Anyone may reproduce, distribute, translate and create derivative works of this article (for both commercial and non-commercial purposes), subject to full attribution to the original publication and authors. The full terms of this licence may be seen at http://creativecommons.org/licences/by/4.0/ legalcode

Disclosure of potential conflicts of interest: The author hereby discloses that they are a full-time employee of an institution of higher education that was one included in the research conducted for this study at the time of writing.

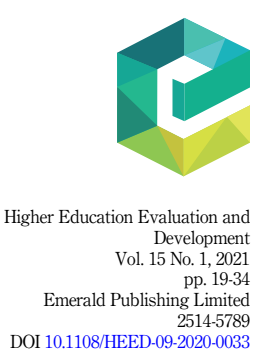


HEED

15,1

offered, as well as the opportunity to harness higher education as a source of revenue and employment (Knight, 2013; Manning et al., 2019). There has also been contention from without and within the higher education institutions (HEIs), resulting from the competing interests of the institutions and the societies in which they are situated (Schartner and Cho, 2017). It is imperative, therefore, for HEIs to effectively manage their organisational strategy in order to simultaneously maximise the benefits presented and minimise the risks to which the domestic HEIs are exposed. This management requires a clear and robust strategy, both at the national level and within the institutions themselves.

East Asia has received significant attention in recent decades, particularly with the success of the "Asian Tigers", the rapid economic development of the People's Republic of China (PRC) and the influence of Confucianism on organisational culture (Marginson, 2011; Mok, 2012; Warner, 2013). This paper seeks to examine the core foci of HEIs in East Asia by analysing MSs as an artefact of organisational strategy. Following research conducted by previous scholars in the field, such as Morphew and Hartley (2006) and Kuenssberg (2011), this research seeks to uncover the strategies used by HEIs in East Asia to respond their rapidly changing environment. The region, comprised of China, Hong Kong, Macao, Japan, Mongolia, North Korea, South Korea and Taiwan, has been touted as one of the strongest in terms of quality and attraction of its HEIs (Marginson, 2011). What is more, as the region continues to develop and as the number of globally mobile higher education students continues to expand, the region is poised to play an even larger role in the global higher education space (Hallinger, 2014). By identifying those institutions which are considered "world class" by the various university rankings organisations, this paper can focus on those qualities which are deemed important by the institutions themselves and national trends in higher education focus and strategy. The aim of this study is to add to the existing body of knowledge in this particular area, following country-specific studies which have been previously conducted in the UAE (Dedousis, 2018), New Zealand and Japan (Chapple, 2015), Italy (Giusepponi and Tavoletti, 2018) and Spain (Arias-Coello et al., 2020) and expanding the scope to encompass the entire East Asian region. While both Morphew and Hartley's (2006) and Kuenssberg's (2011) studies focussed on institution type, this study aims to examine differences and similarities based on the national context. This research was guided by the following question:

(1) How are the MSs of "world class" HEIs in East Asia similar or different based on their location, and to what extent do these differences or similarities reflect national or regional differences and similarities in either organisational or national culture or policy?

\section{Literature review \\ World-class institutions}

There is a significant degree of debate as to what factors can be considered as determinate of "world-class" status amongst HEIs, including access to resources, governance, age, location and access to talent (Allen, 2019). Changing conditions in the region, as well as shifting needs of each jurisdiction, have impacted governmental policy towards higher education across East Asia, often increasing the emphasis on quality with a focus on increasing the number of "world-class" institutions (Sidhu et al., 2016). As many governments are focussing more and more on measurement and quantifying of performance, institutional rankings are being widely used as a measure of an institution's status, often drowning out more nuanced local conceptions of the institutions' quality (Allen, 2019; Lo and Ho, 2020; Shin and Harman, 2009). MSs offer institutions an opportunity to express their own uniqueness to differentiate themselves from their competitors (Dedousis, 2018). At the same time, institutions often relied on short, vague notions which did not give any meaningful direction to the operation of the institution (Dedousis, 2018). 
Higher education in East Asia

Within the East Asian region, significant attention has been paid to both the economic performance of the various economies, as well as the surge in quality and attractiveness of their HEIs (Allen, 2019). This has involved several studies which have sought to link the "Confucian heritage" of the region as both a source of its rapid success, as well as a potential pitfall as it tries to develop effective higher education models which conform to established international mechanisms and form, which have largely been developed within a Western historical and cultural context, while also addressing the cultural expectations, mechanisms and needs of the local population (Choi, 2017; Park, 2018). It has also been suggested, however, that this process of localisation often loses out to pressures for conformity to the globalised higher education system (Allen, 2019) and to develop "world class institutions" at home (Yonezawa, 2018). Universities had to compete with institutions from other countries, and even continents, in order to attract students and faculty. This also led to an increase in the use of more "globalised" languages, especially English, as the medium of instruction, and of most research output, often to the detriment of the local languages and students who speak them, as well as locally focussed research (Kuenssberg, 2011; Sidhu et al., 2016; Yang, 2018). Given these tensions within the region, there is a need to create or adapt measures and conceptualisations for studying higher education which are more applicable to the East Asian context (Yang, 2018).

\section{The mission statement}

"MSs" have emerged, and grown in popularity, amongst HEIs since the 1980s, largely in connection with an increase in managerialism and marketisation of education (Connell and Galasinski, 1998; Lomas, 2007; Ng, 2012) and the requirements of accreditation organisations (Morphew and Hartley, 2006). This was largely done in line with the growing idea that students represented part of the university's consumer base (they chose which courses to take and thus needed to be attracted with marketing initiatives) as well as a resource for the university (generating future "sales", as well as producing research output, and in some cases being linked to government subsidies and funding) (Connell and Galasinski, 1998; Kuznetsov and Kuznetsova, 2011; Lomas, 2007). As a result of this, it was necessary, owing to the existing corporate culture of the time, for universities to codify their raison d'etre as well as their diverse and differentiating characteristics (van Vught, 2008) and identify how this created a competitive advantage which would allow the university to compete in a growing local and international marketplace (Connell and Galasinski, 1998; David, 1989).

MSs are intended to "include a company's long-term purpose and values, core business activities and the features distinguishing it from competitors" (Kuenssberg, 2011, p. 280). The process of formulating an MS is often an important step, in addition to the added benefits of having an MS codified. The creation process helps stakeholders to determine which elements or processes contribute to the efficient functioning of the institution, whilst also signalling to external parties that the institution is governed by a clear set of principles, aimed at achieving a predetermined outcome (Morphew and Hartley, 2006). By examining the MSs of the component companies of the "Fortune 500 List", Pearce and David (1987, p. 109) identified the following core components:

(1) The specification of target customers and markets,

(2) The identification of principal products/services,

(3) The specification of the geographical domain,

(4) The identification of core technologies,

University mission statements 
HEED 15,1

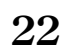

(5) The expression of commitment to survival, growth and profitability,

(6) The specification of key elements in the company philosophy,

(7) The identification of the company self-concept and

(8) The identification of the firm's desired public image.

Of these components, David (1989, p. 91) noted that universities were more likely to include elements such as their "customer, product or service, location, philosophy and self-concept" than corporate organisations. Whilst the function of the MS in the context of higher education remains the same, the makeup is likely to deviate from that found in the corporate context owing to the different environment in which universities operate, the differences in their objectives and the way in which they perceive the roles of their various stakeholders (Lomas, 2007; Morphew and Hartley, 2006). Several scholars have undertaken thematic research of MSs, within a number of contexts, in order to identify the particularity of MSs within higher education, as well as a method of differentiating institutions. Kosmützky and Krücken (2015) sought to determine how MSs are used to identify an institution's niche, as well as how to position itself with regard to its competitors, examining HEIs in Germany. Similarly, Seeber et al. (2019) sought to determine the institutional similarity and differentiation using MSs, whilst also exploring the MS as a tool for constructing an institutional narrative. Wang et al. (2007) also sought to use analysis of MSs as a means of determining the institutional difference between two- and four-year HEIs in Texas, the USA.

Universities' core functions

Aims and values

Stakeholders

Access/inclusion

Service/society

\author{
Research \\ Learning \\ Teaching \\ Education/educational \\ Knowledge \\ Environment (learning/teaching) \\ Ideas \\ Scholarship \\ Excellence \\ Innovation/new \\ Culture/cultural \\ Quality \\ Commitment \\ Enhance \\ Ambition/potential \\ Creativity \\ Students \\ Graduates \\ Staff \\ Open \\ Access/accessible \\ Inclusive \\ Opportunity \\ Participation \\ Lifelong learning \\ Society/social \\ Community \\ Service \\ Partner/partnership
}

Table 1.

Kuenssberg's (2011)

themes and words 
The economy/employment

Competitiveness

Sphere of influence
Economy/economic

Professional/professionalism

Business/enterprise/technology

Vocation/skills

Leader/leadership/leading

Distinctiveness

Best/highest standards

Outstanding

Recognition/reputation

International/world/global

National/[country name]

Local/regional
University mission

statements

Table 1.

Hooley, Cox and Adams the generally accepted model for formulating MSs as being The Ashridge Mission Model (Campbell et al., 1990; as cited in Hooley et al., 1992), consisting of the following four interrelated components: purpose, strategy, values and standards.

This was further developed within the university context by Kuenssberg (2011) into eight major "themes", which were then separated into key "words" to facilitate analysis (see Table 1). While Kuenssberg recorded the number of times key terms were mentioned in MSs in order to assess the significance of each term to the university in question, this study will utilise a more binary analysis, identifying whether a term is used, rather than how often. From this, it will be possible to show whether or not there is a broad consensus in the terms which are included in university MSs within East Asia.

\section{Methodology}

\section{Data collection}

In order to identify "world class" HEIs, this paper will draw from a range of ranking systems to attempt to ameliorate the discrepancies arising from the methodology of each system. A list of applicable institutions was generated by compiling the global university ranking lists of four major international rankings organisations: Quacquarelli Symonds (Quacquarelli Symonds, 2018), Times Higher Education (Times Higher Education, 2018), Shanghai Jiaotong University (ShanghaiRanking Consultancy, 2016) and US News (U.S. News and World Report LP, 2018). The rankings were collected in their most recent iteration on the same day in March 2018. The full lists of entries from each list were transferred to a single list and manually consolidated to remove duplicate entries, so that any institution which appeared on any of the four lists would be included in the working list. The total number of institutions on the consolidated list was 760 . Following this, all universities from outside East Asia were removed, leaving 342 institutions (see Table 1). For the purposes of this analysis, this essay will consider East Asia comprising China, Hong Kong, Macao, North Korea, South Korea, Japan, Mongolia and Taiwan.

From the list of universities, it was then necessary to seek out the university's MS, if available, for analysis. As has been done by previous researchers (Chapple, 2015; CortésSánchez, 2018), the official website of each institution was manually examined by a researcher for mention of the institutional MS. This was done by accessing the English language version of the official website of the institution and examining the "About Us" section. If this was not successful, a Boolean search of the site for the terms "mission" and "mission statement" would be conducted. If the institution had no English language version or the search revealed no MS available on the site, the institution was excluded from the research. This resulted in a list of 84 institutions with publicly available English language MSs on their official website (see Table 2). 


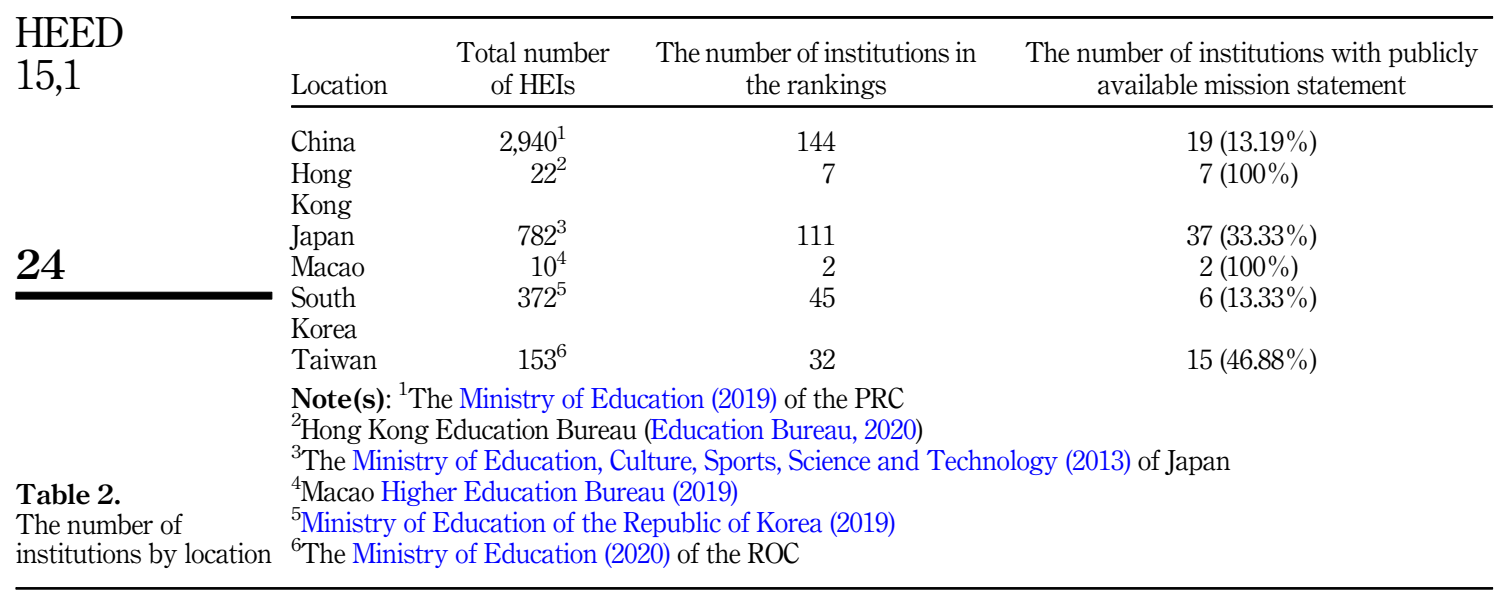

\section{Examining the mission statement}

The analysis to be conducted for this study necessitated that the MSs under examination be in the same language, and as such, only the English language version of the institutional website was examined. The researchers conducted a descriptive content analysis using the key terms in Table 1: the MSs of each university were analysed for the explicit inclusion, each term used to represent the broader "themes" (Neuendorf, 2017). Finally, researchers manually examined each MS in the list to extract terms which were present in the MSs of the institutions collected to identify themes which were not present in Kuenssberg's model. Related terms were collected, and each MS was re-examined for mention of terms related to the themes identified in this way.

\section{Findings}

The MSs collected from East Asian universities vary significantly in terms of length, from six to 1,147 words (average: 101 words), as well as in their focus, specificity and scope. The most common foci were on the core functions of the university and how the institution situated itself within broader society. There was also very little mention of the institutional values, of the relationship with specific stakeholders or on the creation of a diverse and inclusive community within the institution (see Table 3).

Table 3.

Universities' core functions

\begin{tabular}{|c|c|c|c|c|c|c|c|}
\hline & $\begin{array}{c}\text { China } \\
(n=17)\end{array}$ & $\begin{array}{c}\text { Hong } \\
\text { Kong } \\
(n=7)\end{array}$ & $\begin{array}{c}\text { Japan } \\
(n=37)\end{array}$ & $\begin{array}{l}\text { Macao } \\
(n=2)\end{array}$ & $\begin{array}{c}\text { South } \\
\text { Korea } \\
(n=6)\end{array}$ & $\begin{array}{l}\text { Taiwan } \\
(n=15)\end{array}$ & $\begin{array}{c}\text { Total } \\
(n=84)\end{array}$ \\
\hline Research & 6 & 5 & 26 & 1 & 1 & 7 & 46 \\
\hline \multirow[t]{2}{*}{ Learning } & $\begin{array}{r}35 \% \\
1\end{array}$ & $\begin{array}{r}71 \% \\
2\end{array}$ & $\begin{array}{r}68 \% \\
8\end{array}$ & $\begin{array}{r}50 \% \\
-\end{array}$ & $\begin{array}{r}17 \% \\
1\end{array}$ & $\begin{array}{r}47 \% \\
3\end{array}$ & $\begin{array}{r}54 \% \\
15\end{array}$ \\
\hline & $6 \%$ & $29 \%$ & $22 \%$ & - & $17 \%$ & $20 \%$ & $18 \%$ \\
\hline \multirow[t]{2}{*}{ Teaching } & 1 & 2 & 8 & - & 2 & 3 & 16 \\
\hline & $12 \%$ & $57 \%$ & $5 \%$ & - & $33 \%$ & $27 \%$ & $17 \%$ \\
\hline \multirow{2}{*}{$\begin{array}{l}\text { Education/ } \\
\text { educational }\end{array}$} & $\begin{array}{r}5 \\
29 \%\end{array}$ & $\begin{array}{r}4 \\
57 \%\end{array}$ & $\begin{array}{r}25 \\
65 \%\end{array}$ & 1 & $\begin{array}{r}3 \\
50 \%\end{array}$ & $\begin{array}{r}6 \\
40 \%\end{array}$ & $\begin{array}{r}44 \\
52 \%\end{array}$ \\
\hline & $29 \%$ & $57 \%$ & $65 \%$ & $50 \%$ & $50 \%$ & $40 \%$ & $\begin{array}{c}52 \% \\
\text { (continued) }\end{array}$ \\
\hline
\end{tabular}




\begin{tabular}{|c|c|c|c|c|c|c|c|c|}
\hline & $\begin{array}{c}\text { China } \\
(n=17)\end{array}$ & $\begin{array}{c}\text { Hong } \\
\text { Kong } \\
(n=7) \\
\end{array}$ & $\begin{array}{c}\text { Japan } \\
(n=37)\end{array}$ & $\begin{array}{l}\text { Macao } \\
(n=2) \\
\end{array}$ & $\begin{array}{l}\text { South } \\
\text { Korea } \\
(n=6)\end{array}$ & $\begin{array}{l}\text { Taiwan } \\
(n=15)\end{array}$ & $\begin{array}{c}\text { Total } \\
(n=84)\end{array}$ & $\begin{array}{l}\text { University } \\
\text { mission } \\
\text { statements }\end{array}$ \\
\hline \multirow[t]{2}{*}{ Knowledge } & 3 & 6 & 14 & 1 & - & 6 & 30 & \\
\hline & $18 \%$ & $86 \%$ & $35 \%$ & $50 \%$ & - & $40 \%$ & $36 \%$ & \\
\hline \multirow{4}{*}{$\begin{array}{l}\text { Environment } \\
\text { (learning/ } \\
\text { teaching) } \\
\text { Ideas }\end{array}$} & 1 & 1 & 3 & - & - & 1 & 7 & \\
\hline & $6 \%$ & $14 \%$ & $8 \%$ & - & - & $7 \%$ & $7 \%$ & 5 \\
\hline & - & - & 2 & - & - & - & 2 & \\
\hline & - & - & $5 \%$ & - & - & - & $2 \%$ & \\
\hline \multirow[t]{2}{*}{ Scholarship } & - & 2 & 3 & 1 & - & - & 6 & \\
\hline & - & $29 \%$ & $8 \%$ & $50 \%$ & - & - & $7 \%$ & Table 3. \\
\hline
\end{tabular}

\section{Universities' core functions}

Amongst the key terms pertaining to the university's core functions, only Japan was represented in all categories, although only "research" and "education" were mentioned in a majority of cases, while Hong Kong included each word, except "ideas" in at least one institution's MS. Indeed, these two factors were the only two which were mentioned in a majority of cases across the board. The "teaching/learning environment", "ideas" and "scholarship" were all mentioned in less than $10 \%$ of cases (see Table 4).

\begin{tabular}{|c|c|c|c|c|c|c|c|c|}
\hline & $\begin{array}{c}\text { China } \\
(n=17)\end{array}$ & $\begin{array}{c}\text { Hong } \\
\text { Kong } \\
(n=7)\end{array}$ & $\begin{array}{c}\text { Japan } \\
(n=37)\end{array}$ & $\begin{array}{l}\text { Macao } \\
(n=2)\end{array}$ & $\begin{array}{l}\text { South } \\
\text { Korea } \\
(n=6)\end{array}$ & $\begin{array}{l}\text { Taiwan } \\
(n=15)\end{array}$ & $\begin{array}{c}\text { Total } \\
(n=84)\end{array}$ & \\
\hline \multirow{2}{*}{ Excellence } & 1 & 3 & 3 & - & 1 & 3 & 11 & \\
\hline & $6 \%$ & $43 \%$ & $8 \%$ & _- & $17 \%$ & $20 \%$ & $13 \%$ & \\
\hline \multirow{2}{*}{$\begin{array}{l}\text { Innovation/ } \\
\text { new }\end{array}$} & 5 & - & 12 & - & - & 1 & 18 & \\
\hline & $29 \%$ & - & $32 \%$ & - & - & $7 \%$ & $21 \%$ & \\
\hline \multirow{4}{*}{$\begin{array}{l}\text { Culture/ } \\
\text { cultural } \\
\text { Quality }\end{array}$} & 4 & 1 & 13 & 2 & 2 & 6 & 28 & \\
\hline & $24 \%$ & $14 \%$ & $35 \%$ & $100 \%$ & $33 \%$ & $40 \%$ & $33 \%$ & \\
\hline & 2 & 1 & 4 & - & - & 2 & 9 & \\
\hline & $12 \%$ & $14 \%$ & $11 \%$ & - & - & $13 \%$ & $11 \%$ & \\
\hline \multirow[t]{2}{*}{ Commitment } & 1 & - & 2 & - & 1 & 1 & 5 & \\
\hline & $6 \%$ & - & $5 \%$ & - & $17 \%$ & $7 \%$ & $6 \%$ & \\
\hline Enhance & $\begin{array}{r}1 \\
6 \%\end{array}$ & $\begin{array}{r}1 \\
14 \%\end{array}$ & $\begin{array}{r}3 \\
8 \%\end{array}$ & - & - & $\begin{array}{r}2 \\
13 \%\end{array}$ & $\begin{array}{r}7 \\
8 \%\end{array}$ & \\
\hline Ambition/ & - & $\begin{array}{r}14 / 0 \\
-\end{array}$ & 3 & - & - & $\begin{array}{r}13 \% \\
2\end{array}$ & $\begin{array}{r}070 \\
5\end{array}$ & \\
\hline \multirow[b]{2}{*}{$\begin{array}{l}\text { potential } \\
\text { Creativity }\end{array}$} & - & - & $8 \%$ & - & - & $13 \%$ & $6 \%$ & \\
\hline & $\begin{array}{r}1 \\
6 \%\end{array}$ & $\begin{array}{r}1 \\
14 \%\end{array}$ & $\begin{array}{r}2 \\
5 \%\end{array}$ & - & $\begin{array}{r}2 \\
33 \%\end{array}$ & - & $\begin{array}{r}6 \\
7 \%\end{array}$ & Table 4. \\
\hline
\end{tabular}

\section{Aims and values}

Within the region, only "cultural" elements $(33 \%)$ appeared in the statements from all jurisdictions and was the only element within this cluster that was mentioned in the statements from Macanese institutions. Japan was the only jurisdiction that incorporated each element in at least one of its institutions' statements, while China and Taiwan included all except one element (“ambition/potential” and "creativity," respectively) (see Table 5). 


\section{HEED}

\begin{tabular}{|c|c|c|c|c|c|c|c|c|}
\hline \multirow{2}{*}{15,1} & & \multirow[b]{2}{*}{$\begin{array}{c}\text { China } \\
(n=17)\end{array}$} & \multirow[b]{2}{*}{$\begin{array}{c}\text { Hong Kong } \\
(n=7)\end{array}$} & \multirow[b]{2}{*}{$\begin{array}{c}\text { Japan } \\
(n=37)\end{array}$} & \multirow[b]{2}{*}{$\begin{array}{l}\text { Macao } \\
(n=2) \\
\end{array}$} & \multirow[b]{2}{*}{$\begin{array}{l}\text { South } \\
\text { Korea } \\
(n=6)\end{array}$} & \multirow[b]{2}{*}{$\begin{array}{l}\text { Taiwan } \\
(n=15)\end{array}$} & \multirow[b]{2}{*}{$\begin{array}{c}\text { Total } \\
(n=84)\end{array}$} \\
\hline & & & & & & & & \\
\hline \multirow[t]{2}{*}{26} & & $\begin{array}{r}5 \\
29 \%\end{array}$ & $\begin{array}{r}3 \\
43 \%\end{array}$ & $\begin{array}{r}7 \\
19 \%\end{array}$ & - & $\begin{array}{r}1 \\
17 \%\end{array}$ & $\begin{array}{r}7 \\
47 \%\end{array}$ & $\begin{array}{r}23 \\
27 \%\end{array}$ \\
\hline & Graduates & $\begin{array}{ll}- \\
-\end{array}$ & 2 & $\begin{array}{r}2 \\
50\end{array}$ & - & - & - & $\begin{array}{r}4 \\
5 \%\end{array}$ \\
\hline \multirow{2}{*}{$\begin{array}{l}\text { Table 5. } \\
\text { Stakeholders }\end{array}$} & Staff & 1 & 1 & 1 & - & - & - & 3 \\
\hline & & $6 \%$ & $14 \%$ & $3 \%$ & - & - & - & $4 \%$ \\
\hline
\end{tabular}

\section{Stakeholders}

Mention of key stakeholders appeared sparse within the MSs surveyed in this research. Students were mentioned in the MSs from all jurisdictions except Macao. The most inclusive of stakeholder mentions was of students within Taiwanese institutions, where nearly half $(47 \%)$ of those examined made some mention of students. Staff were mentioned in half the jurisdictions examined, although in only one institution each (see Table 6).

\begin{tabular}{|c|c|c|c|c|c|c|c|c|}
\hline & & $\begin{array}{c}\text { China } \\
(n=17)\end{array}$ & $\begin{array}{c}\text { Hong } \\
\text { Kong } \\
(n=7)\end{array}$ & $\begin{array}{c}\text { Japan } \\
(n=37)\end{array}$ & $\begin{array}{l}\text { Macao } \\
(n=2)\end{array}$ & $\begin{array}{l}\text { South } \\
\text { Korea } \\
(n=6)\end{array}$ & $\begin{array}{l}\text { Taiwan } \\
(n=15)\end{array}$ & $\begin{array}{c}\text { Total } \\
(n=84)\end{array}$ \\
\hline & \multirow[t]{2}{*}{ Open } & 2 & - & 6 & - & _- & - & 8 \\
\hline & & $12 \%$ & - & $16 \%$ & - & - & - & $10 \%$ \\
\hline & Access/ & - & - & 1 & - & - & 1 & 2 \\
\hline & accessible & - & - & $3 \%$ & - & - & $7 \%$ & $2 \%$ \\
\hline & \multirow{2}{*}{ Inclusive } & 1 & - & - & - & - & - & 1 \\
\hline & & $6 \%$ & - & - & - & - & - & $1 \%$ \\
\hline & \multirow[t]{2}{*}{ Opportunity } & - & - & 1 & - & - & - & 1 \\
\hline & & - & - & $3 \%$ & - & - & - & $1 \%$ \\
\hline & \multirow[t]{2}{*}{ Participation } & - & - & 1 & - & - & - & 1 \\
\hline & & - & - & $3 \%$ & - & - & - & $1 \%$ \\
\hline Table 6. & Lifelong & - & 2 & 2 & - & - & 2 & 6 \\
\hline Access/inclusion & learning & - & $29 \%$ & $5 \%$ & - & - & $13 \%$ & $7 \%$ \\
\hline
\end{tabular}

\section{Access/inclusion}

Access and inclusion were notably infrequently mentioned within those institutions examined as none of the key terms were included in more than $10 \%$ of the MSs and half were mentioned only once across all statements. The most commonly mentioned key term was "open," which appeared in eight MSs (9\%). It is also noteworthy that both Macao and South Korea did not contain any of the key terms in the statements from any of the institutions surveyed (see Table 7). 


\begin{tabular}{lrrrrrrrr}
\hline & $\begin{array}{c}\text { China } \\
(n=17)\end{array}$ & $\begin{array}{c}\text { Hong } \\
\text { Kong } \\
(n=7)\end{array}$ & $\begin{array}{c}\text { Japan } \\
(n=37)\end{array}$ & $\begin{array}{c}\text { Macao } \\
(n=2)\end{array}$ & $\begin{array}{c}\text { South } \\
\text { Korea } \\
(n=6)\end{array}$ & $\begin{array}{c}\text { Taiwan } \\
(n=15)\end{array}$ & $\begin{array}{c}\text { Total } \\
(n=84)\end{array}$ & $\begin{array}{r}\text { University } \\
\text { mission } \\
\text { Statements }\end{array}$ \\
\hline Society/social & 8 & 4 & 25 & 1 & 3 & 7 & 48 & \\
Community & $47 \%$ & $57 \%$ & $68 \%$ & $50 \%$ & $50 \%$ & $47 \%$ & $57 \%$ & \\
& - & 3 & 11 & - & 1 & 3 & 18 & $\mathbf{2 7}$ \\
Service & - & $43 \%$ & $30 \%$ & - & $17 \%$ & $20 \%$ & $21 \%$ & 11 \\
Partner/ & 1 & 2 & 4 & - & 1 & 3 & $13 \%$ & Table 7. \\
partnership & - & $29 \%$ & $11 \%$ & - & $17 \%$ & $20 \%$ & 3 & Service/society \\
\hline
\end{tabular}

Service/society

More than half of the institutions surveyed made some mention of "society" or "social" in their MSs. Hong Kong, Japan and Taiwan each had some mention of each term in at least one of the MSs examined, whereas Macao referenced only "society/social" in their statements. Reference to "partner/partnership" was less frequent, as it was cited in only three MSs (see Table 8).

\begin{tabular}{|c|c|c|c|c|c|c|c|c|}
\hline & $\begin{array}{l}\text { China } \\
(n=17)\end{array}$ & $\begin{array}{l}\text { Hong Kong } \\
\quad(n=7)\end{array}$ & $\begin{array}{c}\text { Japan } \\
(n=37)\end{array}$ & $\begin{array}{l}\text { Macao } \\
(n=2)\end{array}$ & $\begin{array}{l}\text { South } \\
\text { Korea } \\
(n=6)\end{array}$ & $\begin{array}{c}\text { Taiwan } \\
(n=15)\end{array}$ & $\begin{array}{c}\text { Total } \\
(n=84)\end{array}$ & \\
\hline \multirow[t]{2}{*}{ Economy/economic } & 4 & 2 & 3 & 1 & 1 & 2 & 13 & \\
\hline & $24 \%$ & $29 \%$ & $8 \%$ & $50 \%$ & $17 \%$ & $13 \%$ & $15 \%$ & \\
\hline Professional/ & - & 1 & 5 & - & 1 & 8 & 15 & \\
\hline professionalism & - & $14 \%$ & $14 \%$ & - & $17 \%$ & $53 \%$ & $18 \%$ & \\
\hline Business/enterprise & 1 & 2 & 4 & 1 & 1 & 1 & 10 & \\
\hline /technology & $6 \%$ & $29 \%$ & $11 \%$ & $50 \%$ & $17 \%$ & $7 \%$ & $12 \%$ & Table 8. \\
\hline \multirow[t]{2}{*}{ Vocation/skills } & 1 & - & 6 & - & 1 & 2 & 10 & The economy/ \\
\hline & $6 \%$ & - & $16 \%$ & - & $17 \%$ & $13 \%$ & $12 \%$ & employment \\
\hline
\end{tabular}

\section{The economy/employment}

Amongst the key terms which focus on economic issues, "economy/economic" and "business/enterprise/technology" were represented at least once in all jurisdictions examined and in between 10 and $18 \%$ of institutions overall. Japan, South Korea and Taiwan were represented by at least one institution within their jurisdiction across all the key terms (see Table 9).

\begin{tabular}{|c|c|c|c|c|c|c|c|c|}
\hline & $\begin{array}{c}\text { China } \\
(n=17)\end{array}$ & $\begin{array}{l}\text { Hong Kong } \\
\quad(n=7)\end{array}$ & $\begin{array}{c}\text { Japan } \\
(n=37)\end{array}$ & $\begin{array}{l}\text { Macao } \\
(n=2)\end{array}$ & $\begin{array}{l}\text { South Korea } \\
\quad(n=6)\end{array}$ & $\begin{array}{c}\text { Taiwan } \\
(n=15)\end{array}$ & $\begin{array}{c}\text { Total } \\
(n=84)\end{array}$ & \\
\hline \multirow{4}{*}{$\begin{array}{l}\text { Leader/leadership/ } \\
\text { leading } \\
\text { Distinctiveness }\end{array}$} & 2 & 2 & 10 & 1 & 4 & 4 & 23 & \\
\hline & $12 \%$ & $29 \%$ & $27 \%$ & $50 \%$ & $67 \%$ & $27 \%$ & $27 \%$ & \\
\hline & 1 & - & 1 & - & - & - & 2 & \\
\hline & $6 \%$ & - & $3 \%$ & - & - & - & $2 \%$ & \\
\hline \multirow{4}{*}{$\begin{array}{l}\text { Best/highest } \\
\text { standards } \\
\text { Outstanding }\end{array}$} & 2 & 2 & 3 & - & - & 1 & 8 & \\
\hline & $12 \%$ & $29 \%$ & $8 \%$ & - & - & $7 \%$ & $10 \%$ & \\
\hline & 2 & - & 1 & - & 2 & 1 & 6 & \\
\hline & $12 \%$ & - & $3 \%$ & - & $33 \%$ & $7 \%$ & $7 \%$ & \\
\hline \multirow{2}{*}{$\begin{array}{l}\text { Recognition/ } \\
\text { reputation }\end{array}$} & 1 & - & 2 & - & - & 2 & 5 & Table 9. \\
\hline & $6 \%$ & - & $5 \%$ & - & - & $13 \%$ & $6 \%$ & Competitiveness \\
\hline
\end{tabular}


HEED

15,1

28

\section{Competitiveness}

Amongst the key terms which focussed on competitiveness, "leader/leadership/leading" was the most frequently cited ( $27 \%$ overall) and was mentioned in half of more of the MSs in Macanese and Korean institutions. It was also the only term in this category which appeared in Macanese MSs. There were fewer mentions of the other key terms which all appeared in fewer than $10 \%$ of the MSs examined, with "distinctiveness" appearing in only two of the MSs examined. Both China and Japan included at least one mention of each key term amongst the institutions included in this research (see Table 10).
Table 10.

Sphere of influence

\begin{tabular}{lcccccrc}
\hline & $\begin{array}{c}\text { China } \\
(n=17)\end{array}$ & $\begin{array}{c}\text { Hong } \\
\text { Kong } \\
(n=7)\end{array}$ & $\begin{array}{c}\text { Japan } \\
(n=37)\end{array}$ & $\begin{array}{c}\text { Macao } \\
(n=2)\end{array}$ & $\begin{array}{c}\text { South } \\
\text { Korea } \\
(n=6)\end{array}$ & $\begin{array}{c}\text { Taiwan } \\
(n=15)\end{array}$ & $\begin{array}{c}\text { Total } \\
(n=84)\end{array}$ \\
\hline International/ & 10 & 2 & 25 & 1 & 2 & 9 & 49 \\
world/global & $59 \%$ & $29 \%$ & $68 \%$ & $50 \%$ & $33 \%$ & $60 \%$ & $58 \%$ \\
National/ & 11 & 3 & 11 & 1 & 5 & 4 & 35 \\
[country name] & $65 \%$ & $43 \%$ & $30 \%$ & $50 \%$ & $83 \%$ & $27 \%$ & $42 \%$ \\
Local/regional & 4 & 2 & 10 & - & - & 2 & 18 \\
& $24 \%$ & $29 \%$ & $27 \%$ & - & - & $13 \%$ & $21 \%$ \\
\hline
\end{tabular}

\section{Sphere of influence}

Key terms related to the sphere of influence of the institutions were amongst the more frequently referenced, with all three key terms being mentioned in over $20 \%$ of the institutions included in this research. "International/world/global" was the most frequent with more than half (58\%) of institutions including it in their MSs and with nation being included in $41 \%$ overall. Amongst the jurisdictions included, China, Macao and South Korea all included some mention of the nation in half or more of their institutional MSs. China, Hong Kong, Japan and Taiwan also incorporated some mention of "local/region" focus in their MSs.

\section{New terms}

Amongst the jurisdictions researched in this study, a textual analysis of the combined MSs within each also revealed a number of terms which were not included in the Kuenssberg (2011) study, outlined in the table below (see Table 11).

\begin{tabular}{lccccccc}
\hline & $\begin{array}{c}\text { China } \\
(n=17)\end{array}$ & $\begin{array}{c}\text { Hong Kong } \\
(n=7)\end{array}$ & $\begin{array}{c}\text { Japan } \\
(n=37)\end{array}$ & $\begin{array}{c}\text { Macao } \\
(n=2)\end{array}$ & $\begin{array}{c}\text { South } \\
\text { Korea } \\
(n=6)\end{array}$ & $\begin{array}{c}\text { Taiwan } \\
(n=15)\end{array}$ & $\begin{array}{c}\text { Total } \\
(n=84)\end{array}$ \\
\hline Autonomy/ & - & - & 2 & - & - & - & 2 \\
autonomous & - & - & $5 \%$ & - & - & - & $2 \%$ \\
Beauty & 1 & - & - & - & - & 2 & 3 \\
& $6 \%$ & - & - & - & - & $13 \%$ & $4 \%$ \\
Bridge/link & 1 & - & 1 & - & - & - & 2 \\
Collaboration & $6 \%$ & - & $3 \%$ & - & - & - & $2 \%$ \\
& 2 & - & 7 & - & 1 & 1 & 11 \\
& $12 \%$ & - & $19 \%$ & - & $17 \%$ & $7 \%$ & $13 \%$
\end{tabular}

Table 11.

New terms

(continued) 


\begin{tabular}{|c|c|c|c|c|c|c|c|c|}
\hline & $\begin{array}{l}\text { China } \\
(n=17)\end{array}$ & $\begin{array}{l}\text { Hong Kong } \\
\quad(n=7)\end{array}$ & $\begin{array}{l}\text { Japan } \\
(n=37)\end{array}$ & $\begin{array}{l}\text { Macao } \\
(n=2)\end{array}$ & $\begin{array}{l}\text { South } \\
\text { Korea } \\
(n=6)\end{array}$ & $\begin{array}{r}\text { Taiwan } \\
(n=15)\end{array}$ & $\begin{array}{c}\text { Total } \\
(n=84)\end{array}$ & mission \\
\hline \multirow[t]{2}{*}{ Compassion } & - & - & 1 & - & - & 1 & 2 & \\
\hline & - & - & $3 \%$ & - & - & $7 \%$ & $2 \%$ & \\
\hline \multirow{4}{*}{$\begin{array}{l}\text { Cosmopolitan/ } \\
\text { multicultural } \\
\text { Critical thinking }\end{array}$} & - & - & 2 & - & 1 & 1 & 4 & \\
\hline & - & - & $5 \%$ & - & $17 \%$ & $7 \%$ & $5 \%$ & \\
\hline & - & 2 & - & - & 1 & - & 3 & 29 \\
\hline & - & $29 \%$ & - & - & $17 \%$ & - & $4 \%$ & \\
\hline \multirow[t]{2}{*}{ Dignity/honour } & - & - & 3 & - & 1 & - & 4 & \\
\hline & - & - & $8 \%$ & - & $17 \%$ & - & $5 \%$ & \\
\hline \multirow{4}{*}{$\begin{array}{l}\text { Discipline/ } \\
\text { specialisation } \\
\text { Ethnicity }\end{array}$} & 9 & 1 & 14 & 1 & - & 3 & 28 & \\
\hline & $53 \%$ & $14 \%$ & $38 \%$ & $50 \%$ & - & $20 \%$ & $33 \%$ & \\
\hline & 1 & - & - & - & - & 1 & 2 & \\
\hline & $6 \%$ & - & - & - & - & $7 \%$ & $2 \%$ & \\
\hline \multirow{2}{*}{ Fairness } & - & - & 2 & - & - & - & 2 & \\
\hline & - & - & $5 \%$ & - & - & - & $2 \%$ & \\
\hline Free/freedom/ liberty/ & - & 1 & 11 & - & 1 & - & 13 & \\
\hline liberal/ unfettered & - & $14 \%$ & $30 \%$ & - & $17 \%$ & - & $15 \%$ & \\
\hline \multirow[t]{2}{*}{ Harmony/ harmonious } & 1 & - & 3 & - & - & - & 4 & \\
\hline & $6 \%$ & - & $8 \%$ & - & - & - & $5 \%$ & \\
\hline \multirow[t]{2}{*}{ History/heritage } & - & 1 & 1 & 1 & - & 4 & 7 & \\
\hline & - & $14 \%$ & $3 \%$ & $50 \%$ & - & $27 \%$ & $8 \%$ & \\
\hline Independent/ & - & - & 3 & 1 & - & - & 4 & \\
\hline independence & - & - & $8 \%$ & $50 \%$ & - & - & $5 \%$ & \\
\hline \multirow[t]{2}{*}{ Influence/ influential } & 1 & - & 1 & - & - & 1 & 3 & \\
\hline & $6 \%$ & - & $3 \%$ & - & - & $7 \%$ & $4 \%$ & \\
\hline \multirow[t]{2}{*}{ Integrity } & 2 & - & 3 & 1 & - & 1 & 7 & \\
\hline & $12 \%$ & - & $8 \%$ & $50 \%$ & - & $7 \%$ & $8 \%$ & \\
\hline \multirow[t]{2}{*}{ Morality/ethics } & 1 & 2 & 9 & 1 & - & - & 13 & \\
\hline & $6 \%$ & $29 \%$ & $24 \%$ & $50 \%$ & - & - & $15 \%$ & \\
\hline \multirow{4}{*}{$\begin{array}{l}\text { Nature/natural world/ } \\
\text { ecology } \\
\text { Peace/peaceful }\end{array}$} & 1 & - & 2 & - & - & 1 & 4 & \\
\hline & $6 \%$ & - & $5 \%$ & - & - & $7 \%$ & $5 \%$ & \\
\hline & - & - & 9 & - & - & - & 9 & \\
\hline & - & - & $24 \%$ & - & - & - & $11 \%$ & \\
\hline \multirow[t]{2}{*}{ Progress } & 4 & - & - & - & - & - & 4 & \\
\hline & $24 \%$ & - & - & - & - & - & $5 \%$ & \\
\hline \multirow[t]{2}{*}{ Propriety } & - & - & - & 1 & 1 & - & 2 & \\
\hline & - & - & - & $50 \%$ & $17 \%$ & - & $2 \%$ & \\
\hline \multirow[t]{2}{*}{ Religion/faith/ holiness } & - & 1 & 1 & - & 3 & 2 & 7 & \\
\hline & - & $14 \%$ & $3 \%$ & - & $50 \%$ & $13 \%$ & $8 \%$ & \\
\hline \multirow[t]{2}{*}{ Sincerity } & 1 & - & - & 1 & - & - & 2 & \\
\hline & $6 \%$ & - & - & $50 \%$ & - & - & $2 \%$ & \\
\hline \multirow[t]{2}{*}{ Truth } & 3 & - & 3 & - & 2 & 2 & 10 & \\
\hline & $18 \%$ & - & $8 \%$ & - & $33 \%$ & $13 \%$ & $12 \%$ & \\
\hline \multirow[t]{2}{*}{ World-class } & 3 & - & 3 & - & - & - & 6 & \\
\hline & $18 \%$ & - & $8 \%$ & - & - & - & $7 \%$ & \\
\hline \multirow{2}{*}{$\begin{array}{l}\text { Young generation/next } \\
\text { generation }\end{array}$} & - & - & 4 & - & - & - & 4 & \\
\hline & - & - & $11 \%$ & - & - & - & $5 \%$ & Table 11. \\
\hline
\end{tabular}

Amongst the Chinese institutions studied, the terms which emerged with the greatest frequency were related to a specific discipline (9), progress (4), truth (3) and being world-class (3). In Hong Kong, very few of the terms were mentioned more than once, with the only ones that were being related to critical thinking (2) and morality/ethics (2). In Japan, the discipline or specialised subject was most commonly mentioned (14), followed by freedom/liberty (11), morality (9), peace (9) and collaboration (7). Religion/faith (3) and truth (2) were the only two terms which occurred more than once amongst Korean institutions. In Taiwan, heritage was the most frequent term (4), followed by the discipline/specialisation (3), beauty (2), religion (2) and truth (2). None of the new terms were mentioned more than once amongst Macanese institutions. 
HEED

15,1

\section{Limitations}

The paper covered a wide geographical range, where a large number of different languages are generally used; the reliance of the study on English language MSs excluded a number of potential institutions. Given that the researcher was not versed in all necessary languages used in this region, it is also difficult to ascertain how many institutions were excluded in this way. Also, given the small number of HEIs in Macao, it is difficult to determine how representative the data collected in this study are.

\section{Discussion}

The university's core functions were amongst the most frequently cited using Kuenssberg's (2011) model. The very fact that MSs themselves are a representation of an institutions' conformity to the neoliberal capitalist model of a university as a business, it is not in the least bit surprising that this research would find that those institutions which have spared the effort to formulate internationally accessible (available in English) expressions of managerialism would imply that they would also take the time to formalise the functionalist nature of the institution therein. However, it has also been observed that universities are increasingly adopting managerialist systems and practices which are having a significant impact on academia (Jackson, 2018; Lo, 2016). This may also be related to the low occurrence rate of codified stakeholders from outside the corporate infrastructure of the institution.

Regarding the aims and values of the institutions examined, there was some interesting divergence from Kuenssberg's model. The fact that all jurisdictions made some mention of "culture" may be seen as a reflection of the assumption that there are unique cultural elements to "Asian" institutions which differentiate them significantly from those in the global "west" (Kim, 2016), although some researchers contend that this is not in fact the case (Minkov and Blagoev, 2014). This may also go some way towards explaining the relatively high prevalence of explicit references to "history/heritage" amongst these HEIs, which has not only played a significant part in the rapid rise of many HEIs in the region (Jung and Horta, 2015) but together with "dignity/honour" and "ethnicity" are also important touchstones for stakeholders (Kim, 2016). This may also be reflected in the terminology used to address relationships between the institutions and the wider community. While the original model focussed on "partnerships" within university MSs, "collaboration" was seen in far more of those institutions examined, which differs starkly from the results of a similarly focussed study by Cortés-Sánchez (2018), also mentioned were terms such as "bridge". This also relates to the relatively high instances of "service and society" factors, as per Kuenssberg's model, amongst these universities.

Mention of stakeholders was infrequent, which may suggest that institutions in East Asia prefer not to codify the roles of groups outside of the established management structure, which may decentralise decision-making and reduce the power of managers ( $\mathrm{Ng}$ and Yuen, 2015; Shin and Harman, 2009). Amongst those which mentioned "graduates", these mentions were exclusively in terms of the production of graduates which fulfilled certain criteria, rather than as stakeholders in the university's functioning, and as such, may be better considered to be an expression of the university's societal role. This may be said to be related to the focus amongst institutions in the region on inculcating a certain ethos amongst students, reflected in the relatively high instances of mentions of "morality/ethics", the inclusion of religious terminology, as well as specific values, such as "peace", "freedom" and "harmony".

"Economy/employment" and "competitiveness" were also ranked relatively low amongst Kuenssberg's factors, despite the emphasis previous authors have placed on the use of HEIs as drivers of economic policy within East Asian societies (Lee, 2014; Sanders, 2019). 
However, given that the "sphere of influence" factors relate largely to the reputation of the institution, it may be that these are simply differently phrased amongst East Asian universities, where graduates trade on the cache given by the reputation of the institution directly.

\section{Conclusion}

This paper has attempted to analyse HEIs in an East Asian setting in a systematic way to both examine the regional context using an established method and also to determine which areas differ in this context. While many of the neoliberal, managerial aspects of HEIs as modern institutions perform a similar function in their relative contexts, there was some degree of overlap between those institutions explored in previous research and that which was uncovered by this study. However, given the different cultural context in which East Asian HEIs operate, there is little wonder that institutions here demonstrated different foci and expressed similar ideals in different ways and in some areas expressed very different priorities from their counterparts elsewhere. These included a stronger emphasis on community and relationships, more explicit emphasis on the cultural and historical particularity of the institution, as well as a stronger focus on particular teaching outcomes for students. There was also a stark lack of attention paid to elements which did not fall within the power structure of the university hierarchy, such as the codification of stakeholder involvement, as well as a neglect of issues of inclusion. As previous research has identified, there is a difficulty in identifying what "world-class" entails in relation to HEIs (Allen, 2019). This is also played out in the findings of this paper, given that there was very little uniformity in terms of the factors identified by the HEIs examined during this study. These differences appear to suggest that while the model employed by Kuenssberg (2011) may provide a degree of broad generalisability, it is also heavily focussed on a more "western" educational context, and further research and development would be necessary to uncover areas of particular relevance to different cultural contexts.

\section{References}

Allen, R.M. (2019), "Commensuration of the globalised higher education sector: how university rankings act as a credential for world-class status in China", Compare: A Journal of Comparative and International Education, pp. 1-19, doi: 10.1080/03057925.2019.1686607.

Arias-Coello, A., Simon-Martin, J. and Gonzalo Sanchez-Molero, J.L. (2020), "Mission statements in Spanish universities", Studies in Higher Education, Vol. 45 No. 2, pp. 299-311, doi: 10.1080/ 03075079.2018.1512569.

Chapple, J. (2015), "Mission accomplished? School mission statements in NZ and Japan: what they reveal and conceal", Asia Pacific Education Review, Vol. 16 No. 1, pp. 137-147, doi: 10.1007/ s12564-015-9360-2.

Choi, E.W. (2017), "Higher education regionalization in East Asia", International Higher Education, Vol. 90, pp. 26-28, doi: 10.6017/ihe.2017.90.10008.

Connell, I. and Galasinski, D. (1998), "Academic mission statements: an exercise in negotiation", Discourse and Society, Vol. 9 No. 4, pp. 457-479, doi: 10.1177/0957926598009004003.

Cortés-Sánchez, J.D. (2018), "Mission statements of universities worldwide - text mining and visualization", Intangible Capital, Vol. 14 No. 4, pp. 584-603, doi: 10.3926/ic.1258.

David, F.R. (1989), "How companies define their mission”, Long Range Planning, Vol. 22 No. 1, pp. 90-97, doi: 10.1016/0024-6301(89)90055-1.

Dedousis, E. (2018), "An analysis of mission statements of tertiary institutions: business colleges in UAE”, E-Journal of Business Education and Scholarship of Teaching, Vol. 12 No. 1, pp. 31-51.
University mission statements 
HEED 15,1

Education Bureau (2020), "Local higher education: institutions, education system and policy", available at: http://www.edb.gov.hk/en/edu-system/postsecondary/local-higher-edu/institutions/ index.html (accessed 4 November 2016).

Giusepponi, K. and Tavoletti, E. (2018), "Vision and mission statements in Italian universities: results of an empirical investigation on strategic orientation", Journal of the Knowledge Economy, Vol. 9 No. 1, pp. 301-328, doi: 10.1007/s13132-015-0343-7.

Hallinger, P. (2014), "Riding the tiger of world university rankings in East Asia: where are we heading?”, International Journal of Educational Management, Vol. 28 No. 2, pp. 230-245, doi: 10. 1108/IJEM-11-2012-0126.

Higher Education Bureau (2019), "Macao higher education overview, official website", available at: https://www.dses.gov.mo/eng/overview/introduction (accessed 25 February 2020).

Hooley, G., Cox, A. and Adams, A. (1992), "Our five year mission- to boldly go where no man has been before. ..", Journal of Marketing Management, Vol. 8 No. 1, pp. 35-48.

Jackson, L. (2018), "Reconsidering vulnerability in higher education", Tertiary Education and Management, Vol. 24 No. 3, pp. 232-241, Routledge, doi: 10.1080/13583883.2018.1439999.

Jung, J. and Horta, H. (2015), "The contribution of East Asian countries to internationally published asian higher education research: the role of system development and internationalization", Higher Education Policy, Vol. 28 No. 4, pp. 419-439, doi: 10.1057/hep.2015.15.

Kim, T. (2016), "Internationalisation and development in East Asian higher education: an introduction", Comparative Education, Vol. 52 No. 1, pp. 1-7, doi: 10.1080/03050068.2016.1144309.

Knight, J. (2013), “The changing landscape of higher education internationalisation - for better or worse?", Perspectives: Policy and Practice in Higher Education, Vol. 17 No. 3, pp. 84-90, doi: 10.1080/13603108. 2012.753957.

Kosmützky, A. and Krücken, G. (2015), "Sameness and difference", International Studies of Management and Organization, Vol. 45 No. 2, pp. 137-149, doi: 10.1080/00208825.2015.1006013.

Kuenssberg, S. (2011), "The discourse of self-presentation in Scottish university mission statements", Quality in Higher Education, Vol. 17 No. 3, pp. 279-298, doi: 10.1080/13538322.2011.625205.

Kuznetsov, A. and Kuznetsova, O. (2011), "Looking for ways to increase student motivation: internationalisation and value innovation", Higher Education Quarterly, Vol. 65 No. 4, pp. 353-367, doi: 10.1111/j.1468-2273.2011.00493.x.

Lee, J.T. (2014), "Education hubs and talent development: policymaking and implementation challenges", Higher Education, Vol. 68, pp. 807-823, doi: 10.1007/s10734-014-9745-x.

Lo, W.Y.W. (2016), "The recalibration of neoliberalisation: repoliticising higher education policy in Hong Kong", Higher Education, Springer Netherlands, Vol. 73 No. 5, pp. 1-15, doi: 10.1007/ s10734-016-9989-8.

Lo, W.Y.W. and Hou, A.Y.C. (2020), "A farewell to internationalisation? Striking a balance between global ambition and local needs in higher education in Taiwan", Higher Education, Vol. 80 No. 3, pp. 497-510, doi: 10.1007/s10734-019-00495-0.

Lomas, L. (2007), "Are students customers? Perceptions of academic staff”, Quality in Higher Education, Vol. 13 No. 1, pp. 31-44, doi: 10.1080/13538320701272714.

Manning, K., Kushnazarov, M. and Oleksiyenko, A. (2019), "Contested meanings of international student mobility in Hong Kong and taiwan", Educational Practice and Theory, Vol. 41 No. 1, pp. 51-69, doi: 10.7459/ept/41.1.04.

Marginson, S. (2011), "Higher education in East Asia and Singapore: rise of the confucian model", Higher Education, Vol. 61 No. 5, pp. 587-611, doi: 10.1007/s10734-010-9384-9.

Ministry of Education (2019), "Overview of educational achievements in China in 2018", available at: http://en.moe.gov.cn/documents/reports/201910/t20191022_404775.html (accessed 25 February 2020). 
Ministry of Education of the Republic of Korea (2019), "Statistics: higher education, official website", available at: http://english.moe.go.kr/sub/info.do?m=050103\&s=english (accessed 25 February 2020).

Ministry of Education (2020), Education in Taiwan 2019/2020, Government of the People's Republic of China, Beijing.

Ministry of Education, Culture, Sports, Science and Technology Japan (2013), "Statistics: number of schools, reports and statistics", available at: https:/www.mext.go.jp/en/publication/statistics/ title01/detail01/1373636.htm\#01.

Minkov, M. and Blagoev, V. (2014), "Is there a distinct Asian management culture?", Asia Pacific Business Review, Taylor \& Francis, pp. 209-215, doi: 10.1080/13602381.2013.839136.

Mok, K.H. (2012), "The quest for innovation and entrepreneurship: the changing role of university in East Asia", Globalisation, Societies and Education, Vol. 10 No. 3, pp. 317-335, doi: 10.1080/ 14767724.2012.710120.

Morphew, C.C. and Hartley, M. (2006), "Mission statements: a thematic analysis of rhetoric across institutional type", The Journal of Higher Education, Vol. 77 No. 3, pp. 456-471, doi: 10.1353/jhe. 2006.0025 .

Neuendorf, K.A. (Ed.) (2017), The Content Analysis Guidebook, 2nd ed., Sage Publications, London.

$\mathrm{Ng}$, S.W. (2012), "Rethinking the mission of internationalization of higher education in the Asia-Pacific region", Compare: A Journal of Comparative and International Education, Vol. 42 No. 3, pp. 439-459, doi: 10.1080/03057925.2011.652815.

Ng, S. and Yuen, W.K.G. (2015), "The micro-politics of parental involvement in school education in Hong Kong: ethnocentrism, utilitarianism or policy rhetoric!", Educational Review, Vol. 67 No. 2 , pp. 253-271, doi: 10.1080/00131911.2013.868786.

Park, J. (2018), "Researching higher education in Asia", in Jung, J., Horta, H. and Yonezawa, A. (Eds), Higher Education in Asia: Quality, Excellence and Governance, pp. 51-72, doi: 10.1007/978-98110-4989-7.

Pearce, J.A. and David, F. (1987), "Corporate mission statements: the bottom line", Academy of Management Executive, Vol. 1 No. 2, pp. 109-115, doi: 10.5465/AME.1987.4275821.

Quacquarelli Symonds (2018), "QS world university rankings 2018”, available at: https://www. topuniversities.com/university-rankings/world-university-rankings/2018.

Sanders, J.S. (2019), "National internationalisation of higher education policy in Singapore and Japan: context and competition", Compare: A Journal of Comparative and International Education, Vol. 49 No. 3, pp. 413-429, Routledge, doi: 10.1080/03057925.2017.1417025.

Schartner, A. and Cho, Y. (2017), "Empty signifiers' and 'dreamy ideals': perceptions of the 'international university' among higher education students and staff at a British university", Higher Education, Vol. 74 No. 3, pp. 455-472, doi: 10.1007/s10734-016-0057-1.

Seeber, M., Barberio, V., Huisman, J. and Mampaey, J. (2019), "Factors affecting the content of universities' mission statements: an analysis of the United Kingdom higher education system", Studies in Higher Education, Vol. 44 No. 2, pp. 230-244, doi: 10.1080/03075079.2017. 1349743.

ShanghaiRanking Consultancy (2016), "Academic ranking of world universities 2017”, available at: http://www.shanghairanking.com/ARWU2017.html.

Shin, J.C. and Harman, G. (2009), "New challenges for higher education: global and Asia-Pacific perspectives", Asia Pacific Education Review, Vol. 10 No. 1, pp. 1-13, doi: 10.1007/s12564-0099011-6.

Sidhu, R., Collins, F., Lewis, N. and Yeoh, B. (2016), "Governmental assemblages of internationalising universities: mediating circulation and containment in East Asia", Environment and Planning A: Economy and Space, Vol. 48 No. 8, pp. 1493-1513, doi: 10.1177/0308518X16644255.
University mission statements 
HEED

\section{5,1}

Times Higher Education (2018), "World university rankings 2018", available at: https://www. timeshighereducation.com/world-university-rankings/2018/world-ranking.

U.S. News and World Report LP (2018), "Best global universities rankings", available at: https://www. usnews.com/education/best-global-universities/rankings.

van Vught, F. (2008), "Mission diversity and reputation in higher education", Higher Education Policy, Vol. 21 No. 2, pp. 151-174, doi: 10.1057/hep.2008.5.

Wang, J., Gibson, A.M., Salinas, L., Solis, F. and Slate, J.R. (2007), "Thematic differences in mission statements between four-year public institutions and two-year colleges in Texas", International Electronic Journal for Leadership in Learning, Vol. 11.

Warner, M. (2013), "Managing across diverse cultures in East Asia - introduction”, in Warner, M. (Ed.), Managing across Diverse Cultures in East Asia: Issues and Challenges in a Changing Globalized World, Routledge, London, pp. 3-18.

Yang, R. (2018), "Foil to the west? Interrogating perspectives for observing East Asian higher education", in Jung, J., Horta, H. and Yonezawa, A. (Eds), Researching Higher Education in Asia: History, Development and Future, pp. 37-50, doi: 10.1007/978-981-10-4989-7_3.

Yonezawa, A. (2018), "Japan: world-class universities for social innovation”, International Higher Education, Vol. 96, pp. 21-23, doi: 10.6017/ihe.2019.96.10779.

\section{Further reading}

Davies, S.W. and Glaister, K.W. (1996), "Spurs to higher things? Mission statements of UK universities”, Higher Education Quarterly, Vol. 50 No. 4, pp. 261-294, doi: 10.1111/j.1468-2273. 1996.tb01706.x.

\section{Corresponding author}

Keenan Daniel Manning can be contacted at:kdm852@connect.hku.hk

For instructions on how to order reprints of this article, please visit our website:

www.emeraldgrouppublishing.com/licensing/reprints.htm

Or contact us for further details: permissions@emeraldinsight.com 